\title{
Plants traditionally used for industrial and artisanal purposes in the Arribes del Duero (Spain)
}

\author{
José Antonio González* \& Francisco Amich \\ Duero-Douro Ethnobiological Resources Investigation Group (GRIRED), University of Salamanca. \\ E-37071 Salamanca, Spain. E-mail: ja.gonzalez@usal.es; amich@usal.es
}

\begin{abstract}
González, J.A. \& Amich, F. 2015. Plants traditionally used for industrial and artisanal purposes in the Arribes del Duero (Spain). Anales Jard. Bot. Madrid 72(2): e025.

The present ethnobotanical study, performed between 2005 and 2009 at the Natural Park of the Arribes del Duero (Salamanca-Zamora, Spain), documents the traditional use for technological purposes of 68 vascular plants belonging to 33 families. We interviewed 80 people of different ages native to the zone (mean 72). For each plant species we provide the vernacular terms, the parts used, and the uses made of them (furniture, the elaboration of household utensils, plant fibres, etc.). The species most frequently cited were Quercus ilex L. subsp. ballota (Desf.) Samp., Q. pyrenaica Willd., Ulmus minor Mill. and Olea europaea L. The results of this study confirm the persistence of a rich traditional knowledge in Spanish rural communities; a type of knowledge that affords abundant data for improving and adapting modern production activities to a sustainable model of development, above all as regards the rational consumption of raw materials.
\end{abstract}

Keywords: plant resources, technological use, traditional knowledge, Spain.

\section{INTRODUCTION}

Continuing with our previous studies and ethnobotanical analyses in the rural community of the Arribes del Duero area -henceforth the ARD- (Salamanca-Zamora, western Spain) that began with the publication of the data ranging from refering to medicinal plants (González \& al., 2010), to plants used in the veterinary field, (González \& al., 2011a), wild and semi-domesticated edible plants (González \& al., 2011b), and plants used as insect-repellents and insecticides (González \& al., 2011c), we here report the results obtained concerning the species traditionally used for technological purposes.

As in other Iberian communities (e.g. Blanco \& al., 2000; Fajardo \& al., 2007; Carvalho, 2010) or the Mediterranean region in the broad sense (e.g. Scherrer \& al., 2005; Kargıŏlu \& al., 2010; Nedelcheva \& al., 2011), in our study area traditional use has been made of plants involved in the so-called "material culture", which includes participation in the elaboration of furniture or utensils (for work in the fields, roofing, sweeping implements, etc.). Together with these are other highly varied uses such as the dyeing of textiles. Thus, there is a series of plants whose use has been essential for the inhabitants of the ARD since they first served to meet their basic needs. The best appreciated species are selected according to their physical properties such as robustness, flexibility, etc., and have been exploited sustainably for centuries.

\section{Resumen}

González, J.A. \& Amich, F. 2015. Plantas tradicionalmente usadas con fines industriales y artesanales en las Arribes del Duero (España). Anales Jard. Bot. Madrid 72(2): e025.

El presente estudio etnobotánico, llevado a cabo entre 2005 y 2009 en el Parque Natural de Arribes del Duero (Salamanca-Zamora, España), documenta el uso tradicional con fines tecnológicos de 68 plantas vasculares, pertenecientes a 33 familias. Se entrevistaron a 80 personas nativas de la zona y de diferentes edades (media de 72 años). Para cada especie de planta se proporcionan sus nombres vernáculos, las partes utilizadas y los usos a que son destinadas (fabricación de muebles, elaboración de utensilios domésticos, fibras vegetales, etc.). Las especies más frecuentemente citadas fueron Quercus ilex L. subsp. ballota (Desf.) Samp., Q. pyrenaica Willd., Ulmus minor Mill. y Olea europaea L. El presente estudio confirma la permanencia de un rico conocimiento tradicional en las comunidades rurales españolas, conocimiento que proporciona abundantes datos para mejorar y adecuar las actividades modernas de producción al modelo de desarrollo sostenible, sobre todo en relación al consumo racional de materias primas.

Palabras clave: recursos vegetales, uso tecnológico, conocimiento tradicional, España.

The "industrial and artisanal plants" category encompasses a broad variety of applications. Hence, as posited by some authors (e.g. Carvalho, 2010), there is a certain difficulty in grouping technological uses because the facets of daily rural life in which raw material is obtained from plant species are very heterogeneous. In consonance with the ethnobotanical use-categories defined by the Iberian group of ethnobotanists (see Morales \& al., 2011), in this use-category we include species used in furniture making, the construction of farm implements and the plants used for dyeing and tanning hides.

Thus, the aims of the present work were as follows: (i) to document and analyse the knowledge and traditional use by people from the ARD of different plant species for technological ends; (ii) to contribute to the dissemination of results within the scientific community in order to open a door to research in other disciplines; and (iii) to offer information about a model of traditional sustainable use, bearing in mind that biodiversity conservation is directly related to the use of natural resources.

\section{STUDY AREA}

The economic and demographic characteristics of this territory have been described in detail in González \& al. (2010, 2011a, 2011b, 2011c). Likewise, its floristic, lithological and bioclimatic characteristics can be consulted in Amich \& al. (2004), Bernardos \& al. (2004) and Amich \& Bernardos (2008). 
Although the works cited above include a broad description of the study area, it is worth noting that the ARD, removed from Spanish industrial areas, is a natural space in which its inhabitants have subsisted under survival conditions, and for generations have only seen a few, and then slow, alterations to their customary way of life. Thus, many villages have taken a long time to climb out of a subsistence routine, which formerly allowed the inhabitants to access almost everything necessary for their survival (Hernández Corrochano, 2006).

\section{METHODOLOGY}

The incidence and socio-economic context of the use of plants for technological purposes was studied as part of an ethnobotanical study carried out in the ARD. Between 2005 and 2009, 116 semi-structured interviews were conducted with 80 informants (44 men, 36 women, mean age 72), who were born in the region and all of whom had a sound traditional knowledge (TK) of useful plants. Field work was conducted in 18 localities: 6 in the province of Zamora (localities 1-6) and 12 in the province of Salamanca (localities 7-18) (Fig. 1). Open questions were asked about the use of industrial and artisanal plants to gain insight into past and present use.

The ethnobotanical data collected were analysed focusing on the following use-categories: (1) furniture and household utensils, (2) farming implements and tools (arable and livestock), (3) plant fibres (ropes, sweepers -brushes/brooms-, baskets, textiles and footwear), (4) plants used for dyeing, and (5) plants used for leather tanning.

In the analysis of the data we employed the index of cultural importance $(C I)$ proposed by Tardío \& Pardo-deSantayana (2008), which allows the relative value of each useful plant species to be calculated. First we summed the use-reports (UR) of species $s$ within a certain use-category $\left(u_{i}\right)$ for all the informants (from $i_{1}$ to $i_{N}$ ), and divided this by the total number of informants $(N)$. We then summed the previously calculated quotients for each use-category, from $u_{1}$ to $u_{N C}$ :

$$
C I_{s}=\sum_{u=u_{1}}^{u_{N} C} \sum_{i=i_{1}}^{i_{N}} U R_{u i} / N
$$

This index varied between 0 and the total number of use-categories $(N C)$, in our case 6 . The real value of the $C I$ is much lower than the theoretical maximum because it is difficult for a single species to find uses in all the categories and it was highly unlikely that all informants would have mentioned a use of that species in each use-category.

To evaluate how informants' TK varies in relation to the socio-demographic characteristics, we performed an Analysis of Covariance (ANCOVA), taking "UR" as the variable to model (number of use-reports provided by each informant), using the XLSTAT 2009 program. Likewise, as explanatory variables we took the two items of personal data requested: "age" and "gender" (qualitative values of $\mathrm{m}=$ male or $\mathrm{f}=$ female).

Regarding plant taxonomy and nomenclature we followed "Flora iberica" (Castroviejo, 1986-2015) for the families included therein and "Flora Europaea" (Tutin \& al., 1964-1993) for the remaining ones. Voucher specimens were deposited at SALA, the Herbarium of the University of Salamanca, Spain. In the case of some species for which no voucher was available, a digital photography number (PHO) is included.

\section{RESULTS AND DISCUSSION}

The inhabitants of the ARD use, or have used in the recent past, 68 vascular plants (included in 33 botanical families) for industrial and artisanal purposes. Table 1 lists the plant species cited by at least three informants and includes core botanical and ethnobotanical information about these plants. Most of the species cited were woody plants (43 species, $63 \%$ of the total). The taxa recorded were mainly wild $(\sim 70 \%)$ and comprised approximately $6.2 \%$ of the ca. 1,100 species of vascular plants known in the territory of the ARD.

Among the botanical families best represented in the study are Rosaceae, with 8 species $(12 \%)$, and Poaceae and Fabaceae, with 7 species each (10\%); representing a total of $32 \%$.

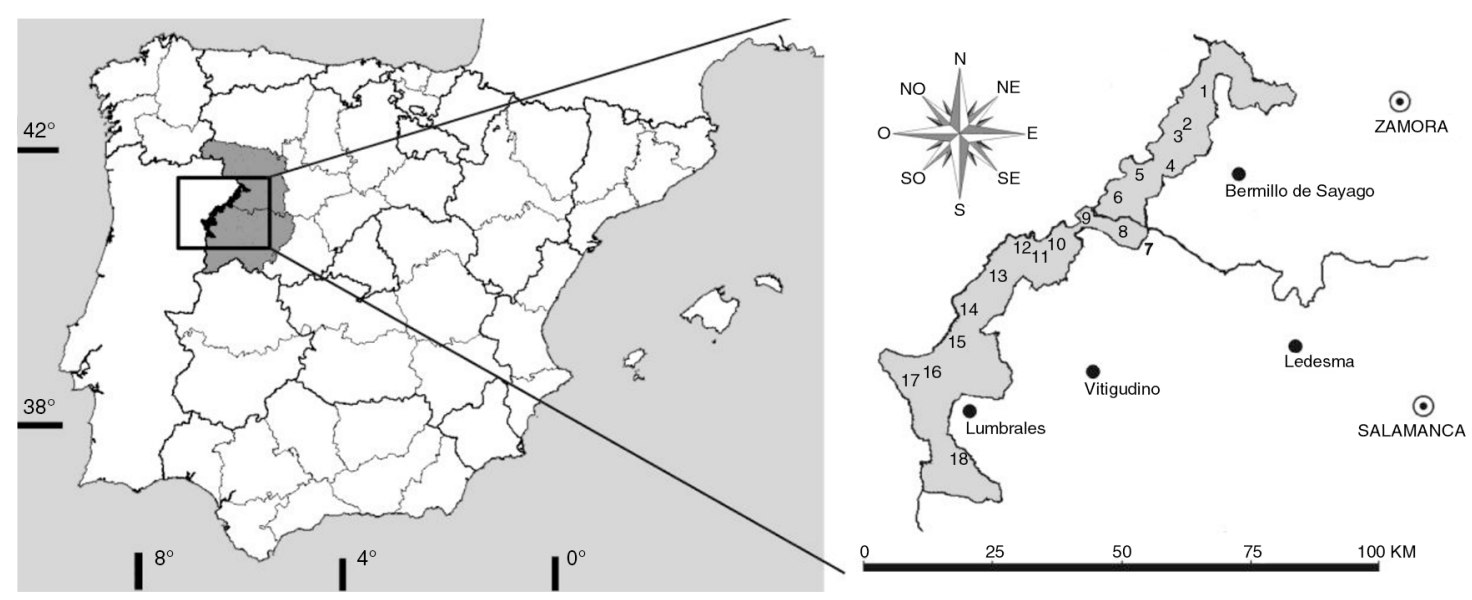

Fig.1. Geographic location of the territory of the Arribes del Duero and the villages where interviews were held. Province of Zamora: 1 , Torregamones; 2, Badilla; 3, Fariza de Sayago; 4, Formariz; 5, Pinilla de Fermoselle; 6, Fermoselle. Province of Salamanca: 7, Almendra; 8, Trabanca; 9, Villarino de Ios Aires; 10, Pereña de la Ribera; 11, Masueco; 12, Aldeadávila de la Ribera; 13, Mieza; 14, Vilvestre; 15, Saucelle; 16, Hinojosa de Duero; 17, La Fregeneda; 18, San Felices de los Gallegos. The edge of the Arribes del Duero Natural Park is shaded. 
Table 1. Vascular plants reported as technological resource and their uses in the rural community of the Arribes del Duero (W Spain). FC $=$ frequency of citation; $\mathrm{Cl}=$ cultural importance index

\begin{tabular}{|c|c|c|c|c|c|c|}
\hline $\begin{array}{l}\text { Families and species (voucher or } \\
\text { digital photograph number) }\end{array}$ & Status $^{1}$ & Local name(s) & Use-categories $^{2}$ & Part(s) used & FC & $\mathrm{Cl}$ \\
\hline \multicolumn{7}{|l|}{ CONIFEROPSIDA } \\
\hline \multicolumn{7}{|l|}{ Cupressaceae } \\
\hline Juniperus oxycedrus L. (SALA 102358) & W & $\begin{array}{l}\text { Enebro, nebro, jimbro, jimbrio, } \\
\text { jimbre, jumbrio, joimbre, joimbrero, } \\
\text { enjumbre, enjumbrio }\end{array}$ & FHU-FIT & Wood, branch & $40-26$ & 0.82 \\
\hline \multicolumn{7}{|l|}{ Pinaceae } \\
\hline $\begin{array}{l}\text { Pinus sp. pl. (P. halepensis Mill., } \\
\text { P. pinaster Aiton, P. pinea L.) }\end{array}$ & C & Pino, piñal & FHU-LET & $\begin{array}{l}\text { Wood, resin, } \\
\text { bark }\end{array}$ & $25-17$ & 0.52 \\
\hline
\end{tabular}

P. pinaster Aiton, $P$. pinea L)

(e.g., SALA 16167)

\section{MAGNOLIOPSIDA}

\section{Aceraceae}

Acer monspessulanum L. (SALA 17318)

\section{Anacardiaceae}

Pistacia terebinthus L. (SALA 17395)

Enguelgue, alguelgue, anguelgue, alguergue, arce, azar

FHU-FIT-PFI

Wood, branch 49-25-15

Rhus coriaria L. (SALA 17392)

geriguera, geregosera, fedegosa

\section{Apiaceae}

Ferula communis L. (SALA 41179)

\section{Asteraceae}

Centaurea aristata Hoffmanns. \& Link (SALA 17181)

Centaurea cyanus L. (SALA 15117)

Centaurea ornata Willd. (SALA 59507)

Chondrilla juncea L. (PHO 47)

Mantisalca salmantica (L.)

Briq. \& Cavillier (SALA 15151)

\section{Betulaceae}

Corylus avellana L. (SALA 17460)

Cannabaceae

Cannabis sativa L. (PHO 38)

\section{Caprifoliaceae}

Sambucus nigra L. (SALA 17435)

\section{Chenopodiaceae}

Spinacea oleracea L. (PHO 180)

\section{Cistaceae}

Cistus ladanifer L. (SALA 18145)

W

W

W

W

W

Cañaleja, cañaheja, cañajeja, caña tufona, caña de burro

FIT

Baleo, baleo fino, baleo montesino

PFI

Baleo cabezudo, azulejo, aciano

Arzolla, zolla, trolla, cardo amarillo

PFI

PFI

Ajunjera, ajinjera, ajonjera, ajujera, jinjeriña, jinjerinas, gengerinas, baleo, balaguera, baleguera, baliadera, baleras Baleo cabezudo, gengerina de cabecilla

C Avellano, avellanal

C Cáñamo

W Canillero, cañilero, saúco, sabugo

FHU-PDY

C Espinaca

W

\section{Cucurbitaceae}

Lagenaria siceraria (Molina) Standl. (PHO 9)

\section{Ericaceae}

Arbutus unedo L. (SALA 16324)

\section{Fabaceae}

Adenocarpus complicatus (L.) J. Gay in Durieu (SALA 19094)
Codeso, escoba, escobajo
FIT

PFI

PDY calabaza del peregrino

W Madroño, madroñera, madroñal

PFI
Stem

Aerial part

Aerial part

Aerial part

Aerial part

Aerial part

5

Stem

16

0.20

Fibre

54

Branch, fruit

25-9

0.42

Leaf (boiled)

4

0.05

Stem, branch, $\quad 30$ leaf, root

Fruit

46

0.57

FHU-FIT-LET

Wood, leaf, bark

15-16-5 
Table 1. (Continued)

\begin{tabular}{|c|c|c|c|c|c|c|}
\hline Families and species & Status $^{1}$ & Local name(s) & Use-categories $^{2}$ & Part(s) used & FC & $\mathrm{Cl}$ \\
\hline $\begin{array}{l}\text { Cytisus multiflorus (L'Hér.) Sweet } \\
\text { (SALA 19214) }\end{array}$ & W & Escoba blanca & $\mathrm{PFI}$ & Branch & 55 & 0.69 \\
\hline $\begin{array}{l}\text { Cytisus scoparius (L.) Link } \\
\text { (SALA 19202) }\end{array}$ & W & $\begin{array}{l}\text { Escoba verde, escoba negra, escoba } \\
\text { rubia, escoba tamariz, escoba } \\
\text { bermeja, retama negra }\end{array}$ & FHU-PFI & Branch, root & $12-71$ & 1.04 \\
\hline $\begin{array}{l}\text { Cytisus striatus (Hill) Rothm. } \\
\text { (SALA 16667) }\end{array}$ & W & Escoba amarilla, escobón, piorno & PFI & Branch & 15 & 0.19 \\
\hline $\begin{array}{l}\text { Echinospartum ibericum Rivas Mart., } \\
\text { Sánchez Mata \& Sancho (SALA 19135) }\end{array}$ & W & $\begin{array}{l}\text { Ardivieja, cambrión, cambronera, } \\
\text { escambrión, piorno, bolaga }\end{array}$ & $\mathrm{PFI}$ & Stem, branch & 10 & 0.12 \\
\hline Genista hystrix Lange (SALA 19033) & W & $\begin{array}{l}\text { Piorno, bolaga, aliaga, abrojo, } \\
\text { escobajos }\end{array}$ & PFI & Branch & 32 & 0.40 \\
\hline $\begin{array}{l}\text { Retama sphaerocarpa (L.) Boiss. (SALA } \\
\text { 16638) }\end{array}$ & W & Retama, piorno blanco, tamariz & FIT-PFI & Branch, root & $7-14$ & 0.26 \\
\hline \multicolumn{7}{|l|}{ Fagaceae } \\
\hline Castanea sativa Mill. (SALA 16332) & W & Castaño, castañera, castañal & FHU-FIT & $\begin{array}{l}\text { Wood, young } \\
\text { shoot, twig }\end{array}$ & $31-12$ & 0.54 \\
\hline Quercus faginea Lam. (SALA 16309) & W & Quejigo, cajigo, roble & FHU-FIT-PDY-LET & $\begin{array}{l}\text { Wood, branch, } \\
\text { twig, bark, gall }\end{array}$ & $17-13-13-9$ & 0.65 \\
\hline $\begin{array}{l}\text { Quercus ilex L. subsp. ballota (Desf.) } \\
\text { Samp. (SALA 16331) }\end{array}$ & W & Encina, ancina, carrasco, carrasca & FHU-FIT-PDY-LET & $\begin{array}{l}\text { Wood, branch, } \\
\text { twig, bark, root }\end{array}$ & $70-70-23-34$ & 2.46 \\
\hline Quercus pyrenaica Willd. (PHO 4) & W & Roble, rebollo, melojo, roble marojo & FHU-FIT-PFI-PDY-LET & $\begin{array}{l}\text { Wood, branch, } \\
\text { twig, bark, gall }\end{array}$ & $53-30-13-24-12$ & 1.65 \\
\hline Quercus suber L. (SALA 17519) & W & $\begin{array}{l}\text { Alcornoque, corchero, sobrero, } \\
\text { sobreiro, jebrero, jebrera, zofrero, } \\
\text { zufreiro }\end{array}$ & FHU-FIT-PFI & $\begin{array}{l}\text { Wood, bark } \\
\text { (cork) }\end{array}$ & $38-40-27$ & 1.31 \\
\hline \multicolumn{7}{|l|}{ Juglandaceae } \\
\hline Juglans regia L. (PHO 20) & $C(S D)$ & Nogal, noguera, nuecera, nuezal & FHU-PDY & $\begin{array}{l}\text { Wood, } \\
\text { immature fruit }\end{array}$ & $50-19$ & 0.86 \\
\hline \multicolumn{7}{|l|}{ Lamiaceae } \\
\hline $\begin{array}{l}\text { Lavandula pedunculata (Mill.) } \\
\text { Cav. (SALA 63374) }\end{array}$ & W & $\begin{array}{l}\text { Tomillo, tomillo de burro, tomillo } \\
\text { moro, tomillo morao }\end{array}$ & FHU-PFI & Aerial part, stem & $9-10$ & 0.24 \\
\hline \multicolumn{7}{|l|}{ Linaceae } \\
\hline Linum usitatissimum L. (PHO 11) & C & Lino & FHU-PFI & Seed, fibre & $40-53$ & 1.16 \\
\hline \multicolumn{7}{|l|}{ Oleaceae } \\
\hline $\begin{array}{l}\text { Fraxinus angustifolia Vahl } \\
\text { (SALA 17874) }\end{array}$ & W & Fresno, freixo & FHU-FIT-PFI & $\begin{array}{l}\text { Wood, young } \\
\text { shoot, twig, } \\
\text { branch }\end{array}$ & $22-43-12$ & 0.96 \\
\hline Olea europaea L. (SALA 17872) & $C(W)$ & Olivo, oliva, olivera & FHU-FIT-PFI & $\begin{array}{l}\text { Wood, young } \\
\text { shoot, root }\end{array}$ & $55-35-33$ & 1.54 \\
\hline Phillyrea angustifolia L. (SALA 17870) & W & Olivilla, labiérnago & PFI & Branch & 20 & 0.25 \\
\hline \multicolumn{7}{|l|}{ Papaveraceae } \\
\hline Papaver rhoeas L. (SALA 16180) & W & Amapola & PDY & Petal & 3 & 0.04 \\
\hline \multicolumn{7}{|l|}{ Phytolaccaceae } \\
\hline Phytolacca americana L. (SALA 16170) & SD & Hierba carmín & PDY & Fruit & 5 & 0.06 \\
\hline \multicolumn{7}{|l|}{ Rosaceae } \\
\hline $\begin{array}{l}\text { Crataegus monogyna Jacq. } \\
\text { (SALA 15394) }\end{array}$ & W & $\begin{array}{l}\text { Espino, espinero, espinera, espino } \\
\text { albar, majuelo, escambrión, galapero }\end{array}$ & $\mathrm{FHU}$ & Wood, thorn & 22 & 0.27 \\
\hline Cydonia oblonga Mill. (SALA 15400) & $\mathrm{C}$ & $\begin{array}{l}\text { Membrillero, membrillo, membrillal, } \\
\text { membrillar, bembrillo }\end{array}$ & $\mathrm{FHU}$ & Wood & 19 & 0.24 \\
\hline Prunus avium L. (SALA 15406) & C & Cerezo, cerezal, caño & MUB-PFI & $\begin{array}{l}\text { Wood, young } \\
\text { shoot }\end{array}$ & $20-5$ & 0.31 \\
\hline Prunus cerasus L. (SALA 15407) & C & Guindo, guindal & $\mathrm{FHU}$ & Wood & 8 & 0.10 \\
\hline $\begin{array}{l}\text { Prunus dulcis (Mill.) D. A. Webb } \\
\text { (SALA 15392) }\end{array}$ & C & Almendro, almendral, almendrera & PFI & Young shoot & 13 & 0.16 \\
\hline Prunus mahaleb L. (SALA 15389) & W & $\begin{array}{l}\text { Guindal bravía, guindera silvestre, } \\
\text { ajinjal, montesina, cerezo montesino }\end{array}$ & FHU-FIT & $\begin{array}{l}\text { Branch, whole } \\
\text { plant }\end{array}$ & $6-33$ & 0.49 \\
\hline Prunus spinosa L. (SALA 15383) & W & Endrino, espino, espinero, bruño & FHU-FIT & Branch, thorn & $13-5$ & 0.22 \\
\hline
\end{tabular}


Table 1. (Continued)

\begin{tabular}{|c|c|c|c|c|c|c|}
\hline Families and species & Status $^{1}$ & Local name(s) & Use-categories $^{2}$ & Part(s) used & FC & $\mathrm{Cl}$ \\
\hline $\begin{array}{l}\text { Rubus ulmifolius Schott s. I. } \\
\text { (SALA 17950) }\end{array}$ & W & Zarza, zarzal, zarcera, zarzamora & $\mathrm{PFI}$ & $\begin{array}{l}\text { Branch, bark, } \\
\text { fibre }\end{array}$ & 20 & 0.25 \\
\hline \multicolumn{7}{|l|}{ Salicaceae } \\
\hline Populus alba L. (SALA 18035) & W & Chopo blanco, álamo & FIT & $\begin{array}{l}\text { Wood, young } \\
\text { shoot, twig }\end{array}$ & 18 & 0.22 \\
\hline Populus nigra L. (PHO 211) & W & Chopa, chopo, chopo del país & FIT-PFI & Wood, branch & $42-23$ & 0.81 \\
\hline $\begin{array}{l}\text { Salix sp. pl. (S. alba L., S. atrocinerea } \\
\text { Brot., S. fragilis L., S. purpurea L., S. } \\
\text { salviifolia Brot., S. triandra L.) (e.g., } \\
\text { SALA } 15867 \text { and SALA 18044) }\end{array}$ & W & Mimbrero, mimbrera, bimbrero & FIT-PFI & Branch & $11-73$ & 1.05 \\
\hline \multicolumn{7}{|l|}{ Santalaceae } \\
\hline Osyris alba L. (SALA 15864) & W & $\begin{array}{l}\text { Punteros, escoba barredera, escoba } \\
\text { rubial pequeña, retama loca }\end{array}$ & PFI-LET & Branch & $25-3$ & 0.35 \\
\hline \multicolumn{7}{|l|}{ Scrophulariaceae } \\
\hline $\begin{array}{l}\text { Odontitella virgata (Link) Rothm. (PHO } \\
\text { 209) }\end{array}$ & W & Baleo, balea & $\mathrm{PFI}$ & Aerial part & 10 & 0.12 \\
\hline \multicolumn{7}{|l|}{ Thymelaeaceae } \\
\hline Daphne gnidium L. (SALA 16742) & W & $\begin{array}{l}\text { Torvisco, torvisquera, trovisco, } \\
\text { truvisco, mañusquera }\end{array}$ & $\mathrm{PFI}$ & Bark & 66 & 0.82 \\
\hline \multicolumn{7}{|l|}{ Ulmaceae } \\
\hline Celtis australis L. (SALA 134759) & W & $\begin{array}{l}\text { Hojaranzo, jaranzo, lodón, lodonero, } \\
\text { dolonero, almez }\end{array}$ & FHU-FIT-PFI & Wood, branch & $15-22-16$ & 0.66 \\
\hline Ulmus minor Mill. (PHO 70) & W & Negrillo, olmo & FHU-FIT-PFI & $\begin{array}{l}\text { Wood, branch, } \\
\text { twig }\end{array}$ & $53-65-22$ & 1.75 \\
\hline \multicolumn{7}{|l|}{ Vitaceae } \\
\hline Vitis vinifera L. (PHO 13/15) & $C$ & Vid, parra & $\mathrm{FHU}$ & Stem, branch & 31 & 0.39 \\
\hline \multicolumn{7}{|l|}{ LILIOPSIDA } \\
\hline \multicolumn{7}{|l|}{ Cyperaceae } \\
\hline Cyperus longus L. (SALA 16918) & W & Juncia, junca, junquilla & $\mathrm{PFI}$ & Stem & 34 & 0.42 \\
\hline $\begin{array}{l}\text { Scirpoides holoschoenus (L.) } \\
\text { Sójak (SALA 16902) }\end{array}$ & w & Junco churrero, junco & $\mathrm{PFI}$ & Stem & 9 & 0.11 \\
\hline \multicolumn{7}{|l|}{ Juncaceae } \\
\hline Juncus effusus L. (SALA 17836) & W & Junco, junco de esteras & $\mathrm{PFI}$ & Stem & 18 & 0.22 \\
\hline \multicolumn{7}{|l|}{ Liliaceae } \\
\hline Allium cepa L. (PHO 104) & $\mathrm{C}$ & Cebolla & PDY-LET & Onion skin, bulb & $9-10$ & 0.24 \\
\hline Ruscus aculeatus L. (SALA 15691) & W & $\begin{array}{l}\text { Rusco, cornicabra, carrasquero del } \\
\text { diablo, barbas de chivo, chibarbo }\end{array}$ & $\mathrm{PFI}$ & Aerial part & 15 & 0.19 \\
\hline \multicolumn{7}{|l|}{ Poaceae } \\
\hline Agrostis truncatula Parl. (SALA 18953) & w & $\begin{array}{l}\text { Ceacilla, ceacina, ciecina, escobillas, } \\
\text { barreplato }\end{array}$ & $\mathrm{PFI}$ & Aerial part & 40 & 0.50 \\
\hline Aira caryophyllea L. (SALA 16012) & w & $\begin{array}{l}\text { Ceacilla, ceacina, ciecina, escobillas, } \\
\text { barreplato }\end{array}$ & $\mathrm{PFI}$ & Aerial part & 15 & 0.19 \\
\hline Arundo donax L. (PHO 214) & $C(S D)$ & Cañas, cañizo & FIT-PFI & Stem & $13-8$ & 0.26 \\
\hline $\begin{array}{l}\text { Phyllostachys aurea Rivière \& C. Rivière } \\
\text { (PHO 217) }\end{array}$ & $C$ & Bambú & FIT-PFI & Stem & $11-5$ & 0.20 \\
\hline Secale cereale L. (PHO 92) & $C$ & Centeno & $\mathrm{PFI}$ & Stem (straw) & 67 & 0.84 \\
\hline Stipa gigantea L. (SALA 18846) & w & Barceo, barcea, barcego, barcega & $\mathrm{PFI}$ & Leaf, root & 75 & 0.94 \\
\hline Stipa tenacissima L. (PHO 220) & M & Esparto, estopa & $\mathrm{PFI}$ & Fibre & 64 & 0.80 \\
\hline \multicolumn{7}{|l|}{ Typhaceae } \\
\hline Typha latifolia L. (PHO 213) & W & $\begin{array}{l}\text { Bayón, enea, anea, aceña, espadaña, } \\
\text { junco }\end{array}$ & $\mathrm{FHU}$ & Leaf & 56 & 0.70 \\
\hline
\end{tabular}

'Status: W=wild (including naturalized); $C=$ cultivated; SD = semi-domesticated (cultivated and reverted to wild status, and neglected cultivated plants); $\mathrm{M}=$ market.

${ }^{2}$ Use-categories: $\mathrm{FHU}=$ furniture and household utensils; FIT =farming implements and tools (arable and livestock); PFI=plant fibres; PDY $=$ plants for dyeing; LET= leather tanning. 
Regarding the use-categories of the plants surveyed, it should be noted that 42 species are used as plant fibre for making brooms/brushes, rope, etc., 29 in the elaboration of artisanal furniture and household utensils, and 23 in the manufacture of farming implements and tools.

The four most important taxa within the technological traditions of the ARD were Quercus ilex L. subsp. ballota (Desf.) Samp. (CI=2.46), Ulmus minor Mill. $(C I=1.75)$, Q. pyrenaica Willd. $(C I=1.65)$ and Olea europaea L. $(C I=1.54)$.

The informants interviewed provided a total of 2,943 UR (average $37 \mathrm{UR} /$ informant; $\max .=77$, $\min .=10$ ). The results of the exploratory analysis conducted regarding the TK amassed by the different informants in terms of their characteristics show that $42 \%$ of the variability of the TK can be explained in terms of age and gender $\left(\mathrm{R}^{2}\right.$ adj. $\left.=0.421\right)$. The remaining variability was due to certain effects (other explanatory variables) that were not, or could not, be measured during the study. Attending the analysis of variance results it can be concluded with a certain degree of confidence that the two explanatory variables do bring a significant amount of information to the model $\left(\mathrm{F}_{2,77}=29.775, \mathrm{P}<0.0001\right.$, confidence interval $=95 \%$ ). Table 2 gives details of the model. Only the age parameter was found to have a significant effect. According to our data, men have provided less information than women in this particular study.

\section{Furniture and bousebold utensils}

According to the older informants, household furniture used to be made entirely of wood and included a exiguous number of elements to cover the inhabitants' basic needs. It was made artisanally if there was someone good at working with wood, otherwise a carpenter's expertise, generally from the same village, was engaged.

The wood most highly valued for making quality furniture is nogal (walnut=Juglans regia L.), a species that is cultivated throughout the territory of the ARD. It is found in villages and surrounding areas, especially in orchards and allotments. The wood of certain fruit trees is also prized, especially cherry and sour cherry trees (Prunus avium L. and P. cerasus L.), because it is hard, heavy, and has a fine texture, which make it highly valued for pieces of furniture-making.

Regarding rustic furniture, of particular interest are the tables used for the typical matanza (the slaughter of homeraised pig for the preparation of hams, sausages ... for later curing). These large tables require tough wood because the slaughtered animal is placed on them for the despiece (quartering). This is why encina (holm-oak = Quercus ilex subsp. ballota) is usually used as the raw material for these tables.

However, most furniture was to be found in the kitchen. For seating, the typical furniture comprised escabeles, small

Table 2. ANCOVA results for the traditional ecological knowledge and model parameters

\begin{tabular}{lrrcc}
\hline Parameter & Value & \multicolumn{1}{c}{ SD } & Student's t & Pr>t \\
\hline Intercept & -38.763 & 10.056 & -3.855 & 0.000 \\
Age & 1.060 & 0.137 & 7.713 & $<0.0001$ \\
Gender-m & -0.425 & 2.792 & -0.152 & 0.879 \\
Gender-f & 0.000 & 0.000 & - & - \\
\hline
\end{tabular}

plank benches without armrests, and escaños, benches with very wide seats, a high back, and armrests on which three people could sit at once. They were usually made of Pyrenean oak (Quercus pyrenaica) and castaño (chestnut $=$ Castanea sativa Mill.). Also common are pine chairs (usually P. halepensis Mill.) with seats made braiding dry leaves of bayón (Typha latifolia L.) and the tajos and tajuelas (low three-legged stools, usually made of negrillo (field elm $=$ Ulmus minor) wood. The vasar, typically made of oak, was a type of kitchen dresser for storing chinaware, cutlery, pans, jugs, etc. These continue to be elements that are still used in a good number of kitchens visited in the ARD -many of them are very old and are of noteworthy artistic value-. In other rooms of the houses the furniture -par excellence- was the arca or baúl (trunks for storing all kinds of things). They would be made of oak or chestnut and were often sculpted, usually with geometric, solar and plant designs (Fig. 2).

Corcho or corcha (cork), a secondary product of the alcornoque (cork oak $=$ Quercus suber L.) is also important in the furniture-making field of the ARD. In particular some artisans still build stools following a technique identical to that recorded in other rural communities studied in Spain (e.g. Blanco \& al., 2000; Verde \& al., 2000). It is also of interest that the ARD forms part of the few enclaves that define the northernmost area of the distribution of the cork oak, such that its ecological value at local level is very important and, as throughout its area of distribution, cork oak woodland conservation plays a very important role in household subsistence economy (Bugalho \& al., 2011). Every 10 or 12 years, in summer, the corcheros harvest the bark of these trees with the simple aid of an axe and wooden wedges/levers. It is crucial to work carefully in order not to damage the casca, or mother layer, from which the next crop will arise (Blanco \& Aragón Pellicer, 2010).

Linaza (linseed) is an oil obtained from flax seeds (Linum usitatissimum L.) to be used as a varnish to protect and conserve all this furniture.

Regarding household utensils, within the framework of the traditional economy of the ARD, based on productive subsistence systems, the elaboration of many objects and utensils for daily use was the responsibility of the inhabitants themselves. The use of simple techniques and knowledge of the whole process by each person are the main characteristics of this

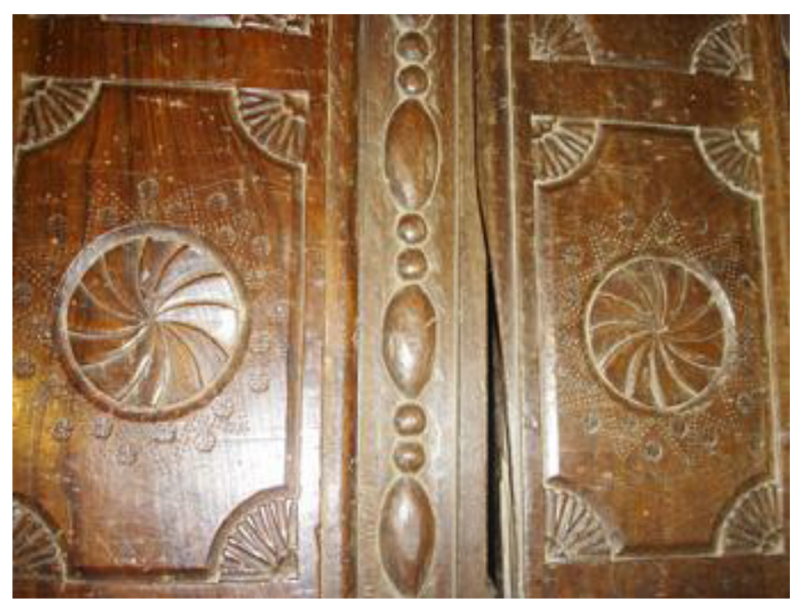

Fig. 2. An example of antique furniture ornamented with solar symbols. 
"domiciliary artisanal work", which at times is indeed hugely appreciated from the artistic point of view, especially in the case of utensils made by shepherds (see Cortés Vázquez, 2003).

For these goods for daily use, many plant species were used, the wood being selected on the basis of its qualities such as hardness, resistance, the ease with which it could be worked, availability, etc. Morteros (grinding mortars) are made of compact, hard and resistant wood such as that of encina, Pyrenean oak and quejigo (Quercus pyrenaica, Q. faginea Lam.), enebro (Juniperus oxycedrus L.), or madroño (Arbutus unedo L.), although in the past, and even today, other woods have been, and are still being, used such as that of fresno (ash =Fraxinus angustifolia Vahl), enguelgue (Acer monspessulanum L.), or espino (Crataegus monogyna Jacq.) -a common phanerophyte throughout the territory of the ARD.

Small kitchen utensils such as salt cellars, bowls, plates, etc., were made of quality woods, such as ash root, the whitishpinkish wood of the membrillero (quince =Cydonia oblonga Mill.) or the compact hard wood of madroño. Also, owing to its marbled pattern, the wood of olive roots, both cultivated and wild (Olea europaea L. var. sylvestris (Mill.) Lehr.), used to be highly prized for the manufacture of these utensils.

With respect to the making of cutlery (spoons and forks), our informants mentioned the use of a large number of species. The wood of enguelgue is highly valued because it is soft to the touch (fewer blisters), light, and very hard, which makes it both resistant and easy to work. The wood of the cornicabra (Pistacia terebinthus L.), hard and of great beauty, is used to make spoons, and even the handles of the blades of knives and pocket-knives. Fresno, espino and enebro were used to make cucharones mondongueros (ladles) and these are still used to stir the mixture of meat, blood and other ingredients necessary to make the traditional cased sausages (chorizo, etc.) known as mondongo.

The traditional matanza (slaughter) requires different elements of plant origin. Artesas (wooden troughs used to store and prepare the meat) are made of encina or castaño. The rigid thorns of species such as Prunus spinosa L. or Crataegus monogyna used to be employed (even today some octogenarians continue to use them) as awls to prick the casings of the uncured sausages before allowing them to cure. These "awls" are locally known under the names of pinchos, espitas or sobinas. We have also been able to document the use of awls made of the stems of Lavandula pedunculata (Mill.) Cav.; they were peeled and sharpened with a knife, after which the sharp tips were charred. In villages in which wine production is important (Fermoselle, Pereña de la Ribera, Villarino de los Aires), these "awls" for the matanza have always been made with a piece of vine shoot because it is easy to place a metal needle of some kind inside the stem. In the past, some of the inhabitants also used the branches of zumaque (sumac=Rbus coriaria L.). Once the meat has been packed into its casing, the products obtained (chorizo, salchichón) can be hung from the thicker branches of a trunk of enebro, used as hooks, hung from the ceiling.

The casks and barrels used to store wine, vinegar or eating olives were made by cask-masters in the ARD. Currently, there are few artisans working in this field, and their time is basically spent fixing old barrels or making new ones on commission (see Panero, 2005). To make the duelas (the staves of barrels), the wood most commonly used locally is that of Q. pyrenaica, although they are sometimes made of chestnut.
Another basic product in the economy of the ARD is cheese. Not so long ago, in home cheese production ringshaped moulds were used; these were made of hojaranzo (Celtis australis L.).

Regarding recipients or containers, the one known as the calabaza de beber -bottle gourd- (Lagenaria siceraria (Molina) Standl.) continues to be cultivated in many allotments. The fruits, of varying shape and size, have been, and continue to be, used to make containers to transport water or wine during daily work in the fields. To make them, the seeds are removed and the shells are allowed to dry. The cap is always made of cork.

For centuries, cork has been part of the daily life of the inhabitants of the ARD. They have used it to make saltcellars, toothpick holders, decorative boxes, or artesas for the traditional slaughter of pigs. However, where cork really comes into the limelight as regards its economic importance is in stoppers for all types of vessels and bottles. Cork is mainly obtained at the localities of Fornillos de Fermoselle and Pinilla de Fermoselle (province of Zamora). Years ago, it was above all used in the cork factory at Almeida de Sayago (Zamora), now closed. Currently cork trees are still being exploited, Portugal being the main buyer.

Not so long ago, the hand-spinning of linen or wool, although today not practised in the rural community being studied, was one of women's daily chores. Apart from working in the fields as productive workers, the women would become involved in other tasks in their "leisure time", among which were spinning and weaving (Hernández Corrochano, 2006). The women always used hand-built spindles and distaffs. To make the spindles and the "palo de la rueca" (the distaff or support for the material to be spun) the pinkishreddish wood of enguelgue was used, which was highly prized because it is soft to the touch, very hard and easy to work. The wood from the field elm, olive tree and Crataegus monogyna was also used. To hold what was to be spun wool, linen, etc. - a crucial part of the operation was that the "palo" should have a stop at one end to prevent the material from slipping off. This stop served as a base to classify these utensils (Frades Morera, 1990). In the most traditional distaffs of the ARD, this was spherical and was constructed by placing a piece of cork on the "palo", around which roots of escoba verde (Cytisus scoparius (L.) Link) were tied to join the two pieces.

For making cachimbas (tobacco pipes) the people would use straight branches from guindal bravia (Prunus mabaleb L.) to make the bowl, since this is an aromatic wood, and they would make the stem from the hollow branches of canillero (Sambucus nigra L.).

Finally, even today it is frequent to see curtains made out of small pieces of wood hanging from doors and windows. These are made by cutting segments of stems, peeling them, threading a piece of wire through them successively and hanging them vertically to keep flies out. In order of frequency, the three woody species used are Sambucus nigra, Rhus coriaria and Vitis vinifera $\mathrm{L}$.

\section{Farming implements and tools (arable and livestock)}

Arable and livestock farming require a large number of tools and a lot of equipment, and plants play an important role in this. To build a pesebrera (multiple manger) the inhabitants 
of the area used to employ whole tree trunks (hollowing out individual "bowls"), particularly Pyrenean oak and holm-oak trunks.

Wood has also been essential as a raw material for methods of transport and, by extension, the economy of the ARD. Carts used to be the main way of transporting merchandise, the wood of negrillo, which is fairly hard and light, was highly valued for many parts of such vehicles. Usually, with the exception of the wheels, which were made of wood from encina, alcornoque or, to a lesser extent, Pyrenean oak, negrillo wood was used to make the other parts of the cart, and it used to be quite abundant in the ARD until the arrival of Dutch elm disease, a fungal disease that has destroyed most of the elm groves on the Iberian Peninsula (Gil \& al., 2000). Additionally, owing to its resistance to traction and putrefaction it was widely used in the construction of water mills and pipes, and it was also used to fence off land and gates.

Other pieces of the structure of carts were made out of the light but resistant wood of fresno (ash). This tree species, together with hojaranzo, has been cited as a raw material used to make yokes "because the wood is heavier than that of the negrillo". These thick, carved beams used to yoke the animals together were made with axes and adzes.

The agriculture of the ARD is characterized by a very low degree of mechanization. Many people continue to till the fields with draft animals and they still use ancestral Roman ploughs, a fairly complex piece of equipment comprising many parts, nearly all of them made of wood. To make them, the inhabitants tended to use encina and, to a lesser extent, Pyrenean oak, fresno or hojaranzo. For example, to make the mancera -the back "handle" of the plough, used to steer the share and push it downwards- they generally used Pyrenean oak. Chopo blanco (Populus alba L.) was used specifically for the shaft of the plough. Its wood was bent in granite moulds, which can still be seen in certain villages as a memory of a life style that is now sadly fading away.

In the elaboration of trillos (ground threshers), thick planks of holm-oak with upwards-curved front ends were used. Underneath, flint chips or small pieces of saw-toothed iron were hammered into the wood. The elastic, hard and compact wood of Celtis australis was used to make horcas (pitchforks, hayforks) to move the parva (straw plus grain) on the threshing floor and bieldos, or briendos, which were wooden instruments for winnowing and for loading the straw onto the cart or the haystack.

The handles of the tools most commonly used in farm work (adzes, axes, etc.) are made out of local wood, chosen for its abundance and easy access. In particular, wood favourites are branches of holm-oak, oak, hojaranzo, fresno or tough shoots of castaño. Less frequently, wild olive, enguelgue, or the dense hard wood of blackthorn (Prunus spinosa), are used. According to our informants, the wood from all these species "is soft to the touch and doesn't hurt your hands".

The cayás and garrotas (walking sticks and clubs), the inseparable companions of shepherds and elderly people, are made of straight branches without knots, usually using shoots. To bend them, they are boiled in water and levered into a curve which is then tied before they have cooled. The TK of the inhabitants of the ARD is witness to the fact that not all types of wood can be bent; only those that, when bent, do not break or crack are of use. The most commonly used wood is that of bojaranzo owing to its fine texture, its density and weight, which make it ideal for making walking sticks (Blanco, 1996a, 2004).

Once dry, the very long stems of Ferula communis L. are used to make light switches, or prods, used to drive livestock, but they are specially used to make cayás ("the green stems were cut and bent and when they were dry they stayed bent"). It should also be noted that currently it is not unusual to see people with sticks made from the canes of Arundo donax or bamboo (Phyllostachys aurea Rivière \& C. Rivière).

Garrotas are used by shepherds as prods to drive their animals in the direction they want them to go. They therefore make them out of strong, resistant wood, especially castaño and olivo silvestre. Regarding the herding of livestock, note should also be taken of the use of long sticks of fresno and enguelgue. Known as varas de aijar, they have a nail at the end to prod draft animals into moving.

During the seasons when olives and almonds are harvested, and also during the montanera (the gathering of acorns from the Fagaceae present in the territory for food for swine), the fruits are knocked off the trees with a long, light flexible pole. These poles are made from the long flexible branches of avellano (Corylus avellana L.) or from the shoots of fresno. The usual practice is to have poles of several lengths, some to knock the fruit off the trees from the ground and shorter ones when doing so from the branches.

In a territory such as the ARD, with so much tradition of livestock-raising and sheep herding, cencerros (cowbells) have always been used to locate animals in the field. The piece that hits the metal (the clapper) is made of tough woods known for their hardness, and is usually made of encina (especially from the heartwood and roots) and enebro. Less used are fresno, madroño and olive tree wood and, occasionally, wood from the stumps and roots of jara (Cistus ladanifer L.) and retama (Retama sphaerocarpa (L.) Boiss.).

As well as the above uses, cork is also used to make beehives. Those made today are square and are formed of five parts: four for the side walls and a cover for the top. Previously, however, they were cylindrical in shape, taking advantage of the rounded shape of the sheets of bark taken when harvesting the bark of cork trees. It was only necessary to join two pieces to obtain a cylinder, whose top part was covered with another small round sheet of cork, nailed in place with long wooden nails made from jara (Fig. 3).



Fig. 3. Traditional cylindrical beehives made with sheets of cork. 
The branches and stems of some species are used as rodrigones: i.e., as supports and guides for climbing species (beans, tomatoes ...). The canes of Arundo donax are widely used and are cultivated in orchards located in damp areas of the warmer parts of the ARD. We interviewed a fair number of informants who stated that they grew bamboo in their homegardens for the same purposes. The long branches of chopa (Populus nigra L.), pruned to make simple stalls for stabling sheep, poles for hen coops or the horizontal part of scarecrows are also used as fork-shaped supports to hold up the branches of fruit trees when loaded with fruit and also as supports for runner beans.

Finally, regarding graftage we documented the use of Prunus mabaleb to graft onto cherry and sour cherry trees, and of Olea europaea var. sylvestris in the case of cultivated olive trees.

\section{Plant fibres}

Plant fibres are natural fibres extracted from several parts of the plant: stems, leaves, etc., and processed so as to obtain products for making ropes and string, brooms/brushes and clothes.

Formerly, rope was hard to come by and people would use whatever was suitable and available to tie things up. The simplest system for anchoring and transporting goods, for example the sheaves of old vines to take home and burn or for heating ovens, consisted of tying them with two branches of escoba blanca (Cytisus multiflorus (L'Hér.) Sweet), popularly known as vencejo.

A very popular solution is the rope made from the bark of Daphne gnidium L. It comes off the wood very easily and the strips are long, flexible and resistant and are used to make rudimentary cords that are very good for tying grafts to vines and fruit trees. They were also formerly used to tie off sacks and brooms/brushes and as "string" in general in the field (the shepherds even used it to put splints on sheep with a broken leg, see González \& al., 2011a).

The stems of Cyperus longus L. are used to enristrar (bind and hang) different vegetables, in particular onions. The leaves of these bulbs are not very resistant, such that braids are made with stems of that species and the onions are attached to them. In the past, they were even used to tie off the casings of cured sausages. Braided cords are also elaborated from the stems of Scirpoides holoschoenus (L.) Sójak and Juncus effusus L. and, formerly, cords were made with the fibres of the stems of zarza (Rubus ulmifolius Schott).

Owing to its economic importance in the zone, note should be taken of the use of barceo (Stipa gigantea L.) in the artisanal production of cheeses. In particular this grass is used to make the cinchos (moulds) to shape the cheese. Their long leaves are braided to form a mould into which the cheese mixture is poured.

One of the customs that still persists in the ARD, as in other rural zones studied in Spain (e.g. Fajardo \& al., 2007), is home-made broom/brush making. Known as barrederos by many of the informants, there are many types of sweeping artefacts that we documented and many plant species used to make them, all depending on the use to which they are to be put, their resistance, and the size required by each task (sweeping the floor, the hearth, etc.). Generally, they are simple, made from readily available local materials.
With fragile plants, such as Agrostis truncatula Parl. and Aira caryophyllea L. the inhabitants make small brushes used to paint houses and also in domestic chores, such as removing cobwebs or dusting.

To sweep the hearth (also to clean ceilings and sweep out corners) harder plants are used, such as barceo, whose leaves are thin, long and form dense bundles. By twisting and tying these leaves it is possible to elaborate very compact and manageable brushes. In the past, these bundles of leaves were sometimes boiled and pressed, obtaining a flatter brush that served to paint the walls with whitewash or to daub mud on the inside of chimneys. Also, with their "root" (macolla), hand brushes were made for sweeping the floor. Again to clean the hearth, brushes were also made of Centaurea cyanus L. and Odontitella virgata (Link) Rothm. This latter species was also used to remove cobwebs and sweep the rest of the house.

For house cleaning, people commonly use escoba verde, a species with a ramified shape that is perfect for such purposes. Escoba blanca is used less, owing to its lesser resistance and hardness. In the past, people also used small switches made of Lavandula pedunculata (with the aerial parts) and larger brooms with branches of codeso (Adenocarpus complicatus (L.) J. Gay) and retama. This latter species was also used to wash out wine casks and barrels.

We also documented the use of "scrapers" made of Genista bystrix Lange or Ruscus aculeatus L. to clean the soot out of the chimney. The inhabitants shaped a kind of ball with a cord attached to opposite sides and this was pulled up and down the chimney by two men.

To clean animal pens, pig sties, corrals, or the front entrance to the house thoroughly, the inhabitants have always used rudimentary large brooms made of different species of Cytisus, Genista bystrix or Chondrilla juncea L. Nevertheless, we have also observed the branches of Phillyrea angustifolia L. or Osyris alba L. being used for such purposes.

Formerly, in threshing, the grain was separated from the chaff and after this it was necessary to clean the threshing floor and collect the grain remaining there. This task of separating the grain from the straw remaining after winnowing was known as balear and it required very hard and resistant brooms, which were hand-held. They were therefore made of the stems and branches of bushy species such as Phillyrea angustifolia, Echinospartum ibericum Rivas Mart., Sánchez Mata \& Sancho, Genista bystrix o de las escobas (Cytisus sp. pl.). Of interest is that several species used to make these brooms are locally known as baleo. Sometimes, a qualification is added to differentiate the different taxa used, but it was necessary to identify which species each informant was referring to in situ. The brooms most commonly used were those made by pressing the stalks of Chondrilla juncea. This utensil was very robust and could cover large surfaces. Other species used were: Mantisalca salmantica (L.) Briq. \& Cavillier, Centaurea aristata Hoffmanns. \& Link or C. ornata Willd. In these cases, the whole flowering plant was used, making use of the weight provided by the flower heads (capitula). When threshing was discontinued, the use of this type of broom also disappeared.

We add here that sometimes a wooden pole was added to the broom to make the job easier. In most of the cases we were able to see and photograph, this pole was a branch of chopa, a cane of Arundo donax, or cultivated bamboo. 
The process of making recipients (baskets, hampers, etc.) and other artefacts from strips or fibres of plant origin is one of the most ancient artisanal practices in the ARD. It has always interested visitors and the inhabitants sell different types of baskets, etc., in tourist areas and markets. Nevertheless, it should be noted that these are products now coming from large firms and even from places such as China. There are only a few people left who will make these products on commission (see Panero, 2005), but in the collective memory of the people interviewed different elements and techniques involved in basket-making still persist in the ARD.

Several species of willow (genus Salix L.) can be found on the banks of rivers and streams in the territory. Some of them have traditionally been used to make artefacts by braiding or interweaving their branches. These species are selected according to what is to be made and the use it is to be put to (Fig. 4). The young branches of the mimbrero or bimbrero, as it is known locally, are almost unbreakable owing to their great flexibility, such that they are used to make canastas, panniers, and large and medium-sized baskets. The most important species is Salix fragilis L. Traditional basketmaking with this type of willow used to be very extended throughout the zone. Sometimes, it was the inhabitants themselves who worked them, while on other occasions specialists would be charged with elaborating them. In some cases, such as in other close-by locales (see Blanco \& Aragón Pellicer, 2010), the species was tended by pruning or planting cuttings in orchards or next to streams. The young flexible branches of the arboreal species (S. alba L., S. atrocinerea Brot.) were used for coarser work. White willow is obtained by stripping the branches of their bark; if the branches are not stripped the material is red.

If the basket to be made was small and fine, arbustive species were used (Cytisus sp. pl., retama or Osyris alba), although they were less resistant than those made of willow. To a lesser extent the fine branches of fresno and chopa were also used in basket-making. Some informants indicated: "we used to take advantage of everything around us". Indeed, the young shoots and the thin branches from the pruning of certain cultivated woody species, in particular from almond trees (Prunus dulcis (Mill.) D.A. Webb), cherry tree and olive tree, were used in popular basket-making. For example, olive branches were used to do rough work because they are less flexible than willow.

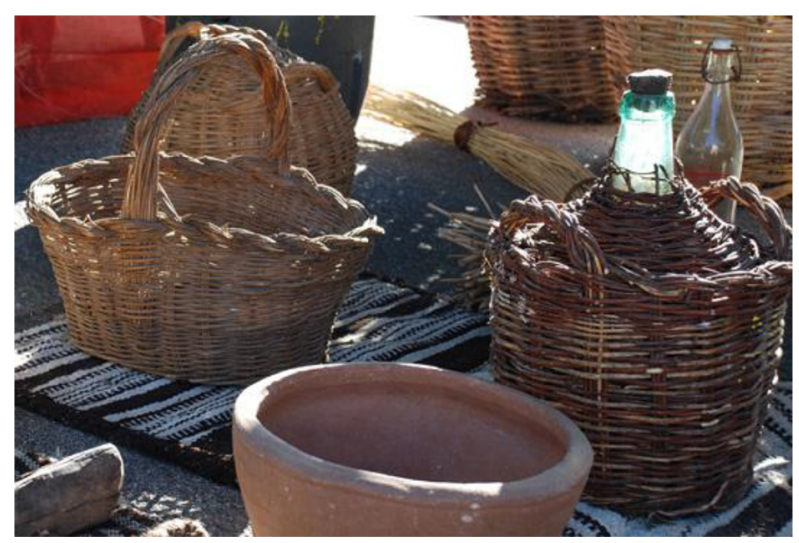

Fig. 4. Different elements characteristic of traditional basket-making in the Arribes del Duero.
The other important plant element used in basket-making in the ARD is the bálago, i.e. long rye straw (Secale cereale L.), which is used exclusively to tie things up with or to weave. It used to be an abundant and accessible raw material (it has been grown in nearly all the localities) for the elaboration of numerous household goods. This straw, for technological uses, is the most appropriate among the cereals because it is longer and more resistant. To collect it the rye was not threshed, since the flints/iron "horseshoes" underneath the trillo would destroy it, rendering it useless. The grains were removed by beating the stems on the ground (the grain would fall leaving the stalks behind intact). The bálago, when woven, was used to make rodetes or rodillas (mats) to support cauldrons when they were taken out of the hearth, for bags, for protective insulation for demijohns, escriños (straw baskets of medium size used to store and preserve different food products) and even jewellery boxes and bassinets. It was also used to fill jergones (straw mattresses) and albardas and colleras (saddles with bags and collars) for beasts of burden.

Strips of the bark of the stems of Rubus ulmifolius (without thorns), and, to a lesser extent, from the branches of mimbre (osier) were used in basket-making to "sew". Together with the bálago, baskets and other goods would be made, especially escriños. A handful of straw was taken and from the base of the recipient the stems were twisted around it and overlaid up to the desired height. The joining of the turns was accomplished with strips of bark, which, apart from providing consistency, added a certain colour and an artistic touch to the recipient.

Hemp (Cannabis sativa L.), historically cultivated in the ARD to obtain plant fibre (see Blanco \& Aragón Pellicer, 2010), was used to make capachos (large bags for storing ground olives) and serones (panniers for equines). Esparto grass (Stipa tenacissima L.), although not present spontaneously in the ARD, has been used as a plant fibre in the territory. It used to be bought outside the area and was used as cord, for tying things and for weaving different types of basket, aguaderas or aguandangas (a vessel for supporting cántaros, i.e. 16-L round bottomed vessels), protection for jugs, demijhons and bottles, and moulds for making cheese.

Until the advent of synthetic materials in artisanal practice and the textile industry, natural fibres were used, of either animal origin, such as wool, or plant origin. The plants used for textiles are characterized by their high content in fibre while at the same time being both flexible and easy to work. In the ARD, the plants used were flax and, to a lesser extent, hemp, both cultivated in orchards.

Together with sheep's wool, flax has traditionally been the raw material for making all apparel in the ARD, and always with the same artisanal premise: simplicity and utility. It was used as a fibre to make linen, which was used for sheets, mattresses, shirts and tablecloths. Estopa (burlap), a coarse fibre, was used for thicker cloth and sacks. It was cultivated across broad swathes of the Iberian Peninsula, but with the introduction of cotton fibre at the beginning of the 20th century linen began to decline in popularity until between the 50s and 80s it ceased to be used at all (Blanco, 1996b). Granzow de la Cerda (1993) has reported the story of how flax was cultivated, processed and used in the locality of Masueco (Salamanca).

By contrast, hemp was only used to make coarse cloth (aprons, sacks, etc.) and also headwear and alpargatas (espadrilles). Hemp fibre was used to sew the edges of the 
long braiding of the bálago with which the hats were made. The technique employed has persisted until the present (Montero, 1951; Panero, 2005). Once the straw has been cut, small handfuls are wetted and twisted into a long braid. The hat is sewn with hemp fibre starting from the top of the crown of the hat and proceeding downwards. Formerly, many homes had looms to help in the families' self-sufficiency, especially regarding the making of shirts and linen sheets and hemp sacks. Currently, these processes have fallen out of use, mainly because of the ease of access to industrial textiles.

Regarding shoe-making, the important cultural role of the style known as chancas should be noted. These are a type of shoe or boot with a wooden sole. Formerly they were the traditional footwear of adults and children; comfortable and orthopaedic -in the sense of being made specifically for the individual's feet-, cool in summer and warm in winter. They were made of wood from bojaranzo, enguelgue, negrillo and, although less so, Pyrenean oak. To avoid wear and tear of the wood, small metal plates were nailed to the sole; these were small "horse shoes" cleverly forged by a smith (see Panero, 2005). Inner soles were made out of cork.

\section{Plants for dyeing}

Although there must have been many plants used in the ARD for dyeing purposes, today those that stained material black, grey or dark brown are remembered. The one most widely used was sumac. This was introduced into the Iberian Peninsula by the Arabs for its tanning properties, due to its high content in tannins - up to 35\% (Macía, 1996) - and it was cultivated in several villages up to about 60 years ago (Mongil, 2000). Today it is found on woodland paths, the edges of roads, stony slopes and in general in marginal agricultural areas such as the remains of abandoned croplands (Amich \& Bernardos, 2008). Frequently, the older people recall their mothers and themselves using the fruits to stain different woollen clothes black (shawls, stockings, etc.). The procedure started by macerating the fruits overnight in water, after which they were crushed and placed in a copper cauldron with boiling water. Then the piece of clothing was introduced together with iron or copper sulphate, which acted as a fixative; that is, making the colour fast.

Another method used for dying, generally used when the clothing was thicker, was based on the use of the bark of holm-oak roots. Following a similar procedure to the above, the clothing would be stained a dark brown. Oak galls were also used, with which it was possible to dye wool grey. Some women recall how their mothers and grandmothers would elaborate a dark brown, almost black, dye with the cáscaras of green walnuts, the fleshy part of the fruit, and used this to paint letters on sacks (for identification) or for dying woollen clothes. These parts contain tannins and juglone (a naphthoquinone that affords a very permanent dye). At Villarino de los Aires (Salamanca) the water used to cook spinach (Spinacea oleracea L.) was employed to obtain a black dye.

Regarding other colours, the mature fruits of bierba carmin (Phytolacca americana L.), a large semi-succulent perennial plant of American origin, were used to obtain a mauve or intensely purple dye, which was used to stain wood and cloth. Occasionally, some people added these berries to red wine to give it a more intense colour, a practice that is not recommendable owing to the toxicity of these fruits (see Nelson \& al., 2007). The petals of poppy flowers (Papaver rhoeas L.) were used to stain wool red, the "cáscaras secas" (skin) of onions (Allium cepa L.) was used for a yellow dye (they have flavonoid pigments), and with the ripe fruits of Sambucus nigra and vinegar as a fixer, a dye was made to dye wool or paint wood in a dark violet colour.

\section{Leather tanning}

In a territory that it eminently devoted to livestockraising, such as the ARD, the hides of animals have traditionally been a very important natural resource. They were used as raw materials for shepherds clothing and for making pellejos and botas (wineskins of different sizes) for transporting wine and olive oil, which have been essential products in the economy of the region. There used to be many tanning and curing shops and there is even a series of families who are known to be nick-named "Los Boteros", whose forebears were devoted to making these skins (see Panero, 2005).

In the long and laborious process of manufacture, tanning substances of plant origin were also used, and a mixture of onion and olive oil was poured into the skins to remove the bitterness and taste of the leather. Following this, pez (pine resin, Pinus pinaster Aiton) was poured into the skins to protect them from rotting.

To be able to use hides it is necessary to subject them to a tanning process that converts them into a new material called leather (flexible, strong and resistant). If the skins are not treated they harden or rot. In the tanning process, the collagen proteins of the skin maintain their flexibility owing to a series of chemical reactions, produced by components known as tanning substances. In nature, the substances able to tan hides are tannins, which are present in many plants. As in the previous section, sumac is the most important species used to tan hides. Its branches were gathered in summer. They would be cut and allowed to dry on the ground for two or three days and then placed in sacks and taken to the tanneries. This plant resource has been used in the ARD since time immemorial (see Tapia Martín \& Pierna Chamorro, 2010).

Also used as a tanning agent -owing to its high tannin content- was oak bark, in particular that of young trees (carrascas) and of its roots. Some families used to sell it to the pieleros (tanners). Also, although to a lesser extent, oak and pine bark, oak galls and bark from the turpentine tree (Pistacia terebinthus) -with a tannin content of up to $60 \%-$ were used, and also the leaves and bark of madroño and branches from Osyris alba.

\section{CONCLUSIONS}

Our results confirm that the ARD, as well as having enormous potential for tourism, is very attractive for scientific interests in biocultural diversity. The TK amassed over generations by its inhabitants provides a wealth of data for improving and directing modern production practices towards a model of sustainable development, above all as regards the rational consumption of raw materials. In all the cases documented, the land has been exploited sustainably owing to the need to maintain resource use in the long-term. 
The utensils, equipment, etc., made -which were basic in past times-are now hard to find, and it is especially rare to see them, unless it is in ethnographic museums or private collections. Many of the traditional uses have been lost. Although the manufacture of brooms and brushes continues, tanning or dyeing plants are no longer in use and basket-making has also been discontinued.

In recent years there has been a trend to substitute local materials by other cheaper non-local artefacts and towards the commerce of objects made elsewhere, such as in China, as (local) artisanal work. These two phenomena are very real and imminent threats to the cultural heritage of the ARD. This trend must be reversed and stress should be placed on the production of traditional local products. This modern philosophy, in which artisanal products are considered as "organic" or "eco-", will be of huge importance for the potential conservation of all these natural resources in the future and in the renewal of the associated knowledge.

Regarding the need to protect these traditional techniques, local and regional institutions should support the education of the young in these matters. Likewise, ethnographic museums and hands-on educational initiatives should implement programs aimed at applying these traditional techniques and conserving the skills related to such knowledge with the structure and characteristics typical of each material, the most suitable tools and traditional designs.

\section{ACKNOWLEDGEMENT}

We are grateful to all people interviewed in this study, for their time and for sharing their knowledge and experience.

\section{REFERENCES}

Amich, F. \& Bernardos, S. 2008. Plantas. In: Calabuig, E.L. (coord.), Arribes del Duero: Guía de la naturaleza: passim. Edilesa. León.

Amich, F., Bernardos, S., Aguiar, C., Fernández-Díez, J. \& Crespí, A. 2004. Taxonomic composition and ecological characteristics of the endemic flora of the lower Duero Basin (Iberian Peninsula). Acta Botanica Gallica 151: 341-352. http://dx.doi.org/10.1080/12538078. 2004.10515439

Bernardos, S., Crespí, A.L., Aguiar, C., Fernández-Díez, F.J. \& Amich, F. 2004. The plant communities of the Rumici indurati-Dianthion lusitani alliance in the Lusitan Duriensean biogeographical sector (NE Portugal and CW Spain). Acta Botanica Gallica 151: 147-164. http://dx.doi.org/ $10.1080 / 12538078.2004 .10516030$

Blanco, E. 1996a. Horcas y bastones de madera de almez. Quercus 128: 8-11.

Blanco, E. 1996b. Cultivo y usos textiles del lino. Quercus 130: 40-41.

Blanco, E. 2004. Pinceladas de etnobotánica salmantina. Salamanca, Revista de Estudios 51: 295-321.

Blanco, E. \& Aragón Pellicer, B. 2010. Plantas con usos artesanales, tecnológicos y etnoagroecológicos. In: Velasco, J.M., Criado, J., \& Blanco, E. (eds.), Usos tradicionales de las plantas en la provincia de Salamanca: 217-286. Diputación de Salamanca. Salamanca.

Blanco, E., Cuadrado, C. \& Morales, R. 2000. Plantas en la cultura material de Fuenlabrada de los Montes (Extremadura, España). Anales del Jardín Botánico de Madrid 58: 145-162. http://dx.doi.org/10.3989/ajbm.2000. v58.i1.146

Bugalho, M.N., Caldeira, M.C., Pereira, J.S., Aronson, J., \& Pausas, J.G 2011. Mediterranean cork oak savannas require human use to sustain biodiversity and ecosystem services. Frontiers in Ecology and the Environment 9: 278-286. http://dx.doi.org/10.1890/100084

Carvalho, A.M. 2010. Plantas y sabiduría popular del Parque Natural de Montesinho: un estudio etnobotánico en Portugal. CSIC. Madrid.

Castroviejo, S. (coord. gen.) 1986-2015. Flora iberica. Plantas vasculares de la Península Ibérica e Islas Baleares, vols. I-XVI(1), XVII-XVIII, XX-XXI. Real Jardín Botánico, CSIC. Madrid.
Cortés Vázquez, L. 2003. Arte popular salmantino. Centro de Estudios Salmantinos-Diputación de Salamanca. Salamanca.

Fajardo, J., Verde, A., Rivera, D. \& Odón, C. 2007. Etnobotánica en la Serrania de Cuenca: las plantas y el hombre. Diputación Provincial de Cuenca. Cuenca.

Frades Morera, M.J. 1990. César Morán Bardón: Obra etnográfica y otros escritos, vol. I - Salamanca. Diputación de Salamanca. Salamanca.

Gil, L., López, R.A. \& García-Nieto, M.E. 2000. Historia de los olmos en la Península Ibérica. In: Gil, L., Solla, A. \& Iglesias, S. (eds.), Los olmos ibéricos: conservación y mejora frente a la grafiosis: 69-114. Organismo Autónomo Parques Nacionales - Ministerio de Medio Ambiente. Madrid.

González, J.A., García-Barriuso, M. \& Amich, F. 2010. Ethnobotanical study of medicinal plants traditionally used in the Arribes del Duero, western Spain. Journal of Ethnopharmacology 131: 343-355. http:// dx.doi.org/10.1016/j.jep.2010.07.022

González, J.A., García-Barriuso, M. \& Amich, F. 2011a. Ethnoveterinary medicine in the Arribes del Duero, western Spain. Veterinary Research Communications 35: 283-310. http://dx.doi.org/10.1007/s11259-0119473-y

González, J.A., García-Barriuso, M. \& Amich, F. 2011b. The consumption of wild and semi-domesticated edible plants in the Arribes del Duero (Salamanca-Zamora, Spain): an analysis of traditional knowledge. Genetic Resources and Crop Evolution 58: 991-1006. http://dx.doi.org/10.1007/ s10722-010-9635-8

González, J.A., García-Barriuso, M., Gordaliza, M. \& Amich, F. 2011c. Traditional plant-based remedies to control insect vectors of disease in the Arribes del Duero (western Spain): An ethnobotanical study. Journal of Ethnopharmacology 138: 595-601. http://dx.doi.org/10.1016/j.jep. 2011.10.003

Granzow de la Cerda, I. (ed.) 1993. Etnobotánica. El mundo vegetal en la tradición. Diputación de Salamanca. Salamanca.

Hernández Corrochano, E. 2006. Mujeres, espacios de equipoder y desarrollo rural. AIBR, Revista de Antropología Iberoamericana 1: 62-79.

Kargıŏlu, M., Cenkci, S., Serteser, A., Konuk, M. \& Vural, G. 2010. Traditional uses of wild plants in the Middle Aegean Region of Turkey. Human Ecology 38: 429-450. http://dx.doi.org/10.1007/s10745-0109318-2

Macía, M.J. 1996. El zumaque, la planta de las tenerías. Quercus 121: 8-10.

Mongil, J. 2000. Antiguo aprovechamiento del zumaque (Rhus coriaria L.) en Castilla y León. Foresta 11: 20-22.

Montero, I. 1951. La gorra popular de paja. Hojas Folklóricas 3: 9.

Morales, R., Tardío, J., Aceituno, L., Molina, M. \& Pardo-de-Santayana, M. 2011. Biodiversidad y Etnobotánica en España. Memorias de la Real Sociedad Española de Historia Natural, $2^{a}$ época, 9: 157-207.

Nedelcheva, A., Dogan, Y., Obratov-Petkovic, D. \& Padure, I.M. 2011. The traditional use of plants for handicrafts in Southeastern Europe. Human Ecology 39: 813-828. http://dx.doi.org/10.1007/s10745-011-9432-9

Nelson, L.S., Shih, R.D. \& Balick, M.J. 2007. Handbook of poisonous and injurious plants, $2^{\text {nd }}$ edn. The New York Botanical Garden-Springer. New York.

Panero, J.A. 2005. Sayago, costumbres, creencias y tradiciones, $2^{\text {nd }}$ edn. ADERISA. Bermillo de Sayago (Zamora).

Scherrer, A.M., Motti, R. \& Weckerle, C.S. 2005. Traditional plant use in the areas of Monte Vesole and Ascea, Cilento National Park (Campania, Southern Italy). Journal of Ethnopharmacology 97: 129-143. http:// dx.doi.org/10.1016/j.jep.2004.11.002

Tapia Martín, R. de \& Pierna Chamorro, J.I. 2010. Plantas empleadas como combustibles y para obtención de productos. In: Velasco, J.M., Criado, J., \& Blanco, E. (eds.), Usos tradicionales de las plantas en la provincia de Salamanca: 287-305. Diputación de Salamanca. Salamanca.

Tardío, J. \& Pardo-de-Santayana, M. 2008. Cultural Importance indices A comparative analysis based on the useful wild plants of southern Cantabria (Northern Spain). Economic Botany 62: 24-39. http://dx.doi. org/10.1007/s12231-007-9004-5

Tutin, T., Heywood, V., Burges, A., Moore, D., Valentine, D., Walters, M. \& Webb, D. (eds.) 1964-1980. Flora Europaea, vols. 1-5. Cambridge University Press. Cambridge.

Verde, A., Fajardo, J., Rivera, D. \& Odón, C. 2000. Etnobotánica en el entorno del Parque Nacional de Cabañeros. Parques Nacionales-Ministerio de Medio Ambiente. Madrid.

Associate Editor: Ramón Morales Received: 1-XI-2012 Accepted: 23-IX-2015 